
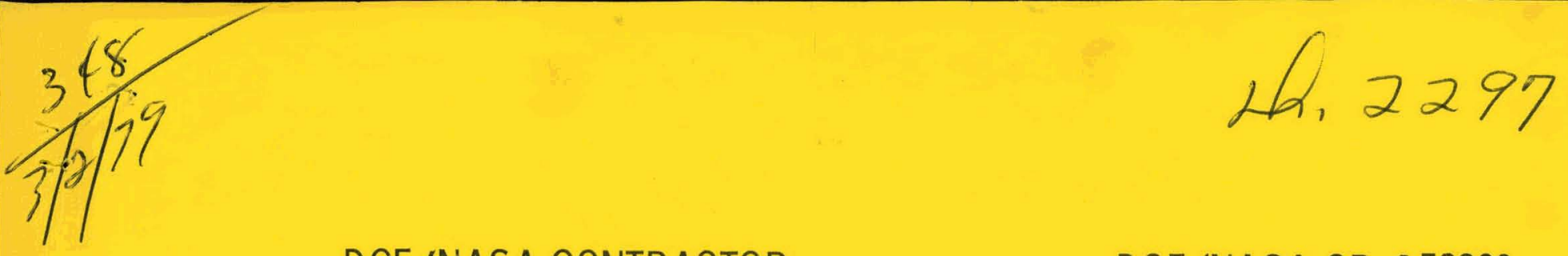

DOE /NASA CONTRACTOR

DOE/NASA CR-150899

REPORT

\title{
LONG TERM WEATHERING EFFECTS ON THE THERMAL PERFORMANCE OF THE SUNWORKS (LIQUID) SOLAR COLLECTOR
}

Prepared by

Wyle Laboratories

Solar Energy Systems Division

Huntsville, Alabama 35805

Under subcontract with

IBM Corporation, Federal Systems Division, Huntsville, Alabama 35805

Contract NAS8-32036

National Aeronautics and Space Administration

George C. Marshall Space Flight Center, Alabama 38512

For the U. S. Department of Energy

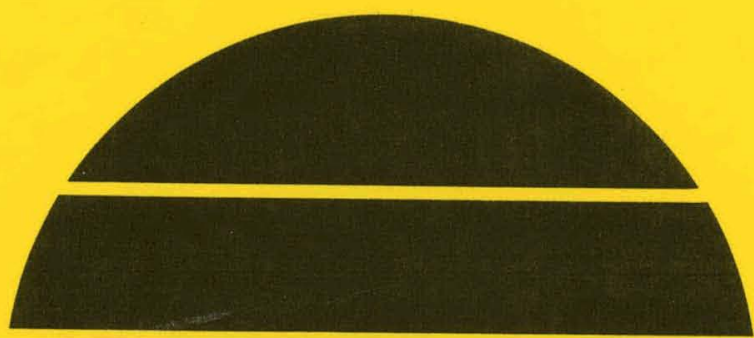

\section{U.S. Department of Energy}




\section{DISCLAIMER}

This report was prepared as an account of work sponsored by an agency of the United States Government. Neither the United States Government nor any agency Thereof, nor any of their employees, makes any warranty, express or implied, or assumes any legal liability or responsibility for the accuracy, completeness, or usefulness of any information, apparatus, product, or process disclosed, or represents that its use would not infringe privately owned rights. Reference herein to any specific commercial product, process, or service by trade name, trademark, manufacturer, or otherwise does not necessarily constitute or imply its endorsement, recommendation, or favoring by the United States Government or any agency thereof. The views and opinions of authors expressed herein do not necessarily state or reflect those of the United States Government or any agency thereof. 


\section{DISCLAIMER}

Portions of this document may be illegible in electronic image products. Images are produced from the best available original document. 
This report was prepared to document work sponsored by the United States Government. Nelther the United States nor its agents the Unfted States Departmant of Energy, the United States National Aeronautics and Space Adminfetration, nor any federsl employees, nor any of thefl contractors, sutccrtractors or the1r employees, make any warranty, express or 1 miflited, or assume any legal llability or responsibility for the accuiscy, completeness, or usefulness of any information, apparatus, product or process disclosed, or represent that its use would not Infringe privately owned rights. 
TECHNICAL REPORT ST ANDARD TITLE PAGE

\begin{tabular}{|c|c|}
\hline $\begin{array}{l}\text { 1. REPORT NO. } \\
\text { DOE/NASA CR-150899 }\end{array}$ & 2. GOVERNMENT ACCESSION NO. \\
\hline
\end{tabular}

7. AUTHOR(S)

9. PERFORMING ORGANIZATION NAME AND ADDRESS

Wyle Laboratóries

Solar Energy Systems Division

Huntsville, Alabama 35805

12. SPONSORING AGENCY NAME AND ADORESS

National Aeronautics and Space Administration

Washington, D. C. 20546
3. RECIPIENT'S CATALOG NO.

5. REPORT DATE January 1979

6. PERFORMING ORGANIZATION CODE 8. PERFORMING ORGANIZATION REPORT \# 10. WORK UNIT NO.

11. CONTRACT OR GRANT NO. NAS8-32036

13. TYPE OF REPORI' \& PERIOD COVERED

Contractor Report

14. SPONSORING AGENCY CODE

15. SUPPLEMENTARY NOTES

This work was done under the technical management of Mr. Norman Thomas, George C. Marshall Space Flight Center, Alabama.

16. ABSTRACT

This report presents the test procedures used and the results obtained during the evaluation test program of the Sunworks single-covered liquid solar collector. The tests were performed under simulated conditions, following long-term exposure to natural weathering conditions.

The Sunworks collector is a flat-plate solar collector. The absorber plate is copper with copper tubes bonded by soft solder, and is coated with Enthon selective black wilh an absorptivity factor of $.87 \sim .92$ and an emissivity factor of $.10 \sim .20$. It has a single glass cover of $3 / 16^{\prime \prime}$ tempered glass and weighs about 115 pounds. The overall dimensions of the collector are $36^{\prime \prime} \times 84^{\prime \prime} \times 4 "$.

For further information on the Sunworks collector test procedures and performance evialuation, see DOE/ NASA CR-150573.

The Sunworks solar collector is manufactured by Sunworks, P. O. Box 1004, New Haven, Connecticut 06508.

17. KEY W.ORDS

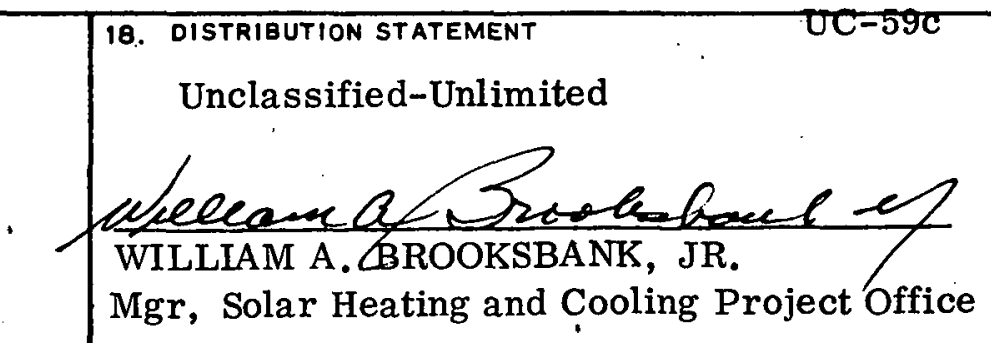

19. SECURITY CLASSIF. (of thle roport)

20. SECURITY CLASSIF. (ol thlo page)

Unclassified

Unclassified

21. NO. OF PAGES
10

22. PRICE

NTIS 
THIS PAGE

\section{WAS INTENTIONALLY LEFT BLANK}


TABLE OF CONTENTS

Page No.

1.0

SUMMARY

1

2.0

PURPOSE

2

3.0

REFERENCES

2

4.0

TEST REQUIREMENTS AND PROCEDURES

3

4.1 Collector Thermal Efficiency Test Requirements

4.2 Test Procedure

5.0

ANALYSIS AND RESULTS

5

5.1 Thermal Performance Test

5

TABLE I

SUNWORKS LIQUID COLLECTOR PERFORMANCE RECHECK AFTER LONG TERM EXPOSURE TO NATURAL WEATHERING CONDITIONS

Figure 1 .

Comparison of Thermal Performance of Sunworks Liquid Collector Before and After Long Term Exposure to Natural Weathering Conditions

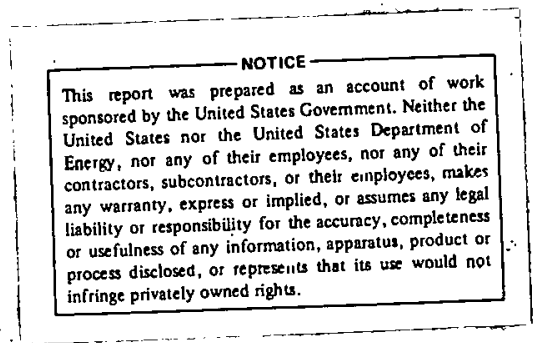


Thermal performance tests were conducted on the Sunworks liquid collector, following long term exposure to natural weathering conditions. The collector was mounted on the weathering test stand at the solar Test Facility at Marshall space Flight Center, Alabama, with exposure to the natural ambient environment. The collector was under stagnation conditions from September 2, 1977, to December 30,1977 , when the collector was integrated into an intermittently active system. The collector remained in intermittently active/stagnant conditions until June 1, 1978, when it was returned to the weathering stand under stagnation conditions through August 15, 1978. The collector was retested at the Marshall Space Flight Center Solar Simulator on August 16, 1978. The total weathering period was approximately eleven and one-half months.

Visual inspection of the collector, prior to the re-test, indicated no noticeable deterioration. The test results also indicated that no detectable degradation in performance had resulted from the weathering. A comparison of the test results for the re-test and the original thermal efficiency test are shown in Figure 1. The necessary supporting data recorded for the re-test are shown in Table 1. 
The purpose of this report is to present the test procedures used and the test results obtained during an evaluation test program. The test program was conducted to obtain thermal performance data on a sunworks $(\mathrm{S} / \mathrm{N}$ Ll158G) single-covered liquid solar collector under simulated conditions (Reference 3.1), following long term exposure to natural weathering conditions. The tests were conducted utilizing the Marshall Space. Flight Center Solar Simulator in accordance with the test procedures specified in Reference 3.2 and the test requirements of Reference 3.3 .

$3.0 \quad$ REFERENCES

3.1 DOE/NASA CR -150573

Indoor Test for Thermal Performance Evaluation of the Sunworks (Liquid) Solar collector

$3.2 \quad$ MTCP -FA-SHAC -400

Procedure for. Operation of the MSFC Solar Simulator Facility

3.3 ASHRAE-93-77

Method of Testing to Determine the Thermal Performance of Solar Collectors 
Thermal performance evaluation criteria shall be identical to that of Reference 3.1 or as close as possible. Data shall be obtained at inlet temperatures of 0,25 , 50 and $100^{\circ} \mathrm{F}$ above the ambient temperature at a liquid flow rate of $285 \mathrm{lb} / \mathrm{hr}(0.57 \mathrm{GPM})$ at a solar insolation rate of $300 \mathrm{BTU} / \mathrm{Hr}^{\cdot} \cdot \mathrm{Ft}^{2}$ and a wind speed of $7.5 \mathrm{mph}$. The following data shall be recorded during the test. at each test condition.

1. Ambient temperature.

2. Collector inlet liquid temperature.

3. Collector outlet liquid temperature.

4. Collector differential temperature.

5. Differential pressure across collector.

6. Liquid flow rate.

7. Insolation rate.

8. Wind speed.

4.2 Test Procedure

1. Mount test specimen on test table at a $45^{\circ}$ angle with respect to the floor.

2. Assure that simulator lamp array is adjusted to an angle of $45^{\circ}$ with respect to the floor.

3. Align the test table so that the test specimen's vertical centerline coincides with the vertical centerline of the lamp array and the distance from the top of the test specimen to the lens plane of the lamp array is 9 feet.

4. Insulate all pipes.

5. Assure that data acquisition system is operational.

6. Start liquid flow loop and establish a flow rate of $285 \mathrm{Lb} / \mathrm{Hr}$ ( $0.57 \mathrm{GPM})$.

7. Establish the wind speed of $7.5 \mathrm{mph}$.

8. Power up simulator and establish a solar flux level of $300 \mathrm{BTU} / \mathrm{Ft}^{2} \cdot \mathrm{Hr}$. 
9. Determine the ambient air temperature.

10. Adjust the inlet temperature of the collector to the ambient air temperature value.

11. After steady state conditions have been established, record data for a minimum of five minutes.

12. Repeat steps 9, 10, and 11, changing the liquid inlet temperature as necessary until data has been obtained for each test condition specified in Paragraph 4.1.

13. Upon completion of testing, power down simulator and liquid loop.

14. Inform data control group that simulator operation has terillinated. 
5.1 Thermal Performance Test

The analysis of data contained in this report is in accordance with the National Bureau of Standards recommended approach. This approach is outlined below.

The efficiency of a collector is stated as:

$n=\frac{q_{u} / A}{I}=\frac{\dot{m} c_{t f}\left(t_{f, e}-t_{f, i}\right)}{I}$

where:

$q_{u}=$ rate of useful energy extracted from the

. . Solar Collector (BTU/Hr)

$A=$ Gross collector area $\left(\mathrm{Ft}^{2}\right)$

I. = Total solar energy incident upon the plane of the solar colleçtor per unit time per. unit area $\left(\mathrm{BTU} / \mathrm{Hr} \cdot \mathrm{Ft}^{2}\right)$

$\dot{\mathrm{m}}=$ Mass flow rate of the transfer liquid through the colfector per unit area of the collector $\left(\mathrm{Lbm} / \mathrm{Ft}^{2} \cdot \mathrm{Hr}\right)$

$C_{t P}=$ Specific heat of the transfer liquid (BTU/Lb- ${ }^{\circ} \mathrm{F}$ )

$\begin{aligned} t_{f, e}= & \begin{array}{l}\text { Temperature of the transfer liquid leaving the } \\ \text { collector }(\circ \mathrm{F})\end{array}\end{aligned}$ $t_{f, i}=\begin{aligned} & \text { Temperature of the transfer liquid entering the } \\ & \text { collector }\left({ }^{\circ} \mathrm{F}\right)\end{aligned}$

Rewriting Equation (1) in terms of the total collector area yield:

$n=\frac{(\dot{m} A) c_{t f}\left(t_{f, e}-t_{f, i}\right)}{(I A)}=\frac{\dot{M} c_{t f}\left(t_{f, e}-t_{f, i}\right)}{P_{i}}$

Notice that:

$P_{i}=I A=$ Total Power Incident on the Collector.

$\mathrm{mA}=\dot{\mathrm{M}}=$ Total Mass Flow Rate through the collector. Therefore $\dot{M} C_{t f}\left(t_{f, e}-t_{f, i}\right)=$ Total Power collected by
the collector. 
5.1 Thermal Performance Test (Continued)

Substitution in Equation (2) results in:

$$
x=\frac{\text { Pabs }}{\text { Pinc }}
$$

where:

$$
\begin{aligned}
& \text { Pabs }=\text { Total collected power } \\
& \text { Pinc }=\text { Total incident power }
\end{aligned}
$$

This value of efficiency is expressed as a percentage by multiplying by 100. This expression for percent efficiency is :

$$
\text { Collector Efficiency }=\frac{\text { Pabs }}{\text { Pinc }} \times 100
$$

or from Equation (2), collector efficiency is defined by the equation:

$$
8 \text { Eff. }=\frac{\dot{M} C_{t f}\left(t_{f, e}-t_{f, i}\right)}{\text { Pinc }} \times 100
$$

Each term in Equation (5) was measured and recorded independently during the test. The calculated values of efficiency were determined at sixty-second intervals. The mean value of efficiency was determined over a fiveminute period during which the test conditions remained in a quasi-steady state. Each five-minute period constitutes one "data point" as is graphically depicted on a plot of percent efficiency versus

$$
\left(\left(t_{i}-t_{a}\right) / I\right)
$$

where:

$$
\begin{aligned}
& t_{i}=\text { Liquid inlet temperature }\left({ }^{\circ} \mathrm{F}\right) \\
& t_{a}=\text { Ambient temperature }\left({ }^{\circ} \mathrm{F}\right) \\
& \left.I=\text { Incident flux per unit area (BTU/Hr. Ft }{ }^{2}\right)
\end{aligned}
$$

The abscissa term $\left(\left(t_{i}-t_{a}\right) / I\right)$ was used to normalize the effect of operating at slightly different values of $I$, $t_{i}$, and $t_{a}$. The results are shown graphically in Figure 1 with the supporting test data given in Table $I$. 
TABLE I

SUNWORKS LIQUID COLLECTOR PERFORMANCE RECFECK

AFTER LONG TERM EXPOSURE TO NATURAL WEATHERING CONDITIONS

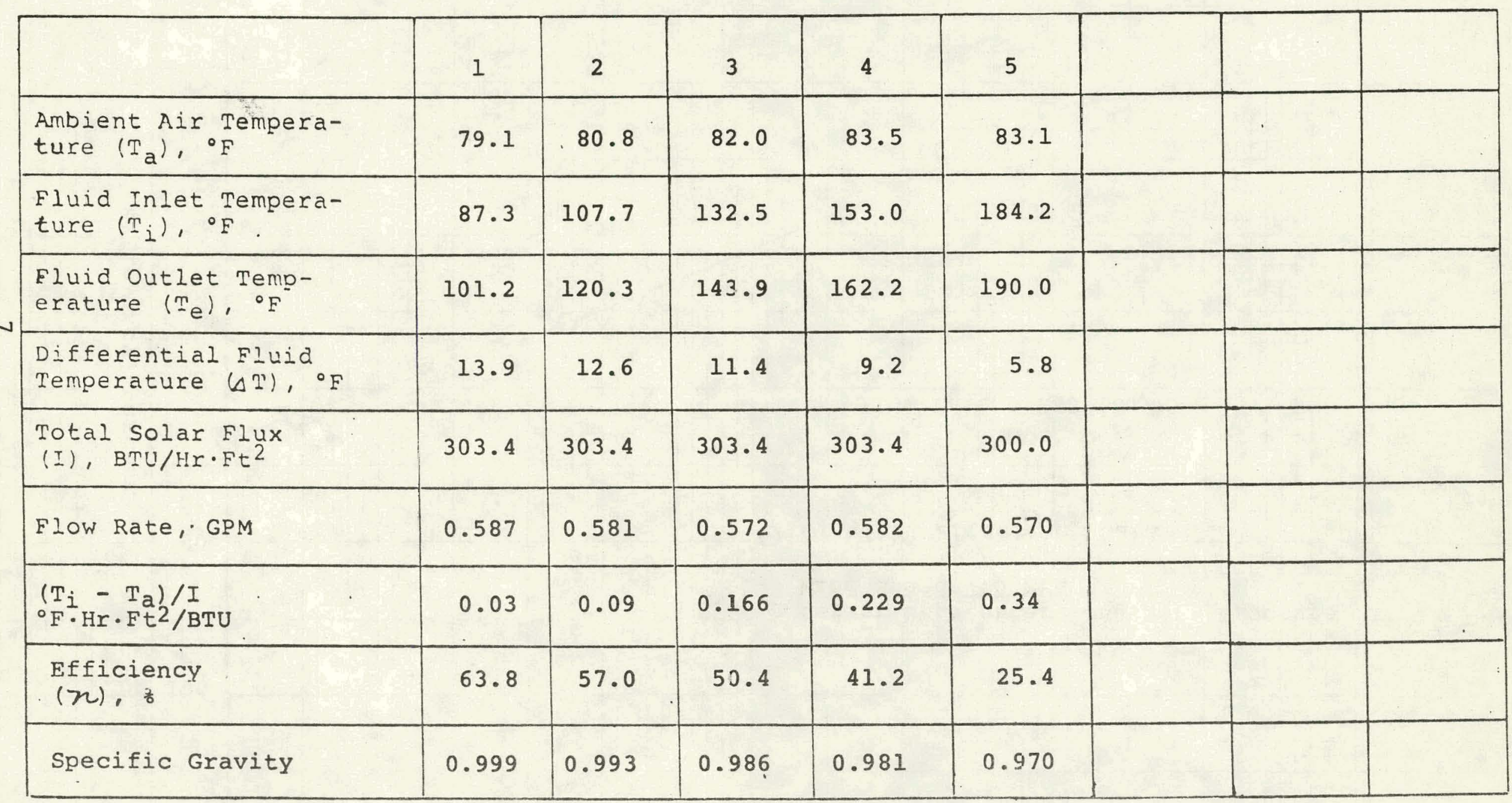




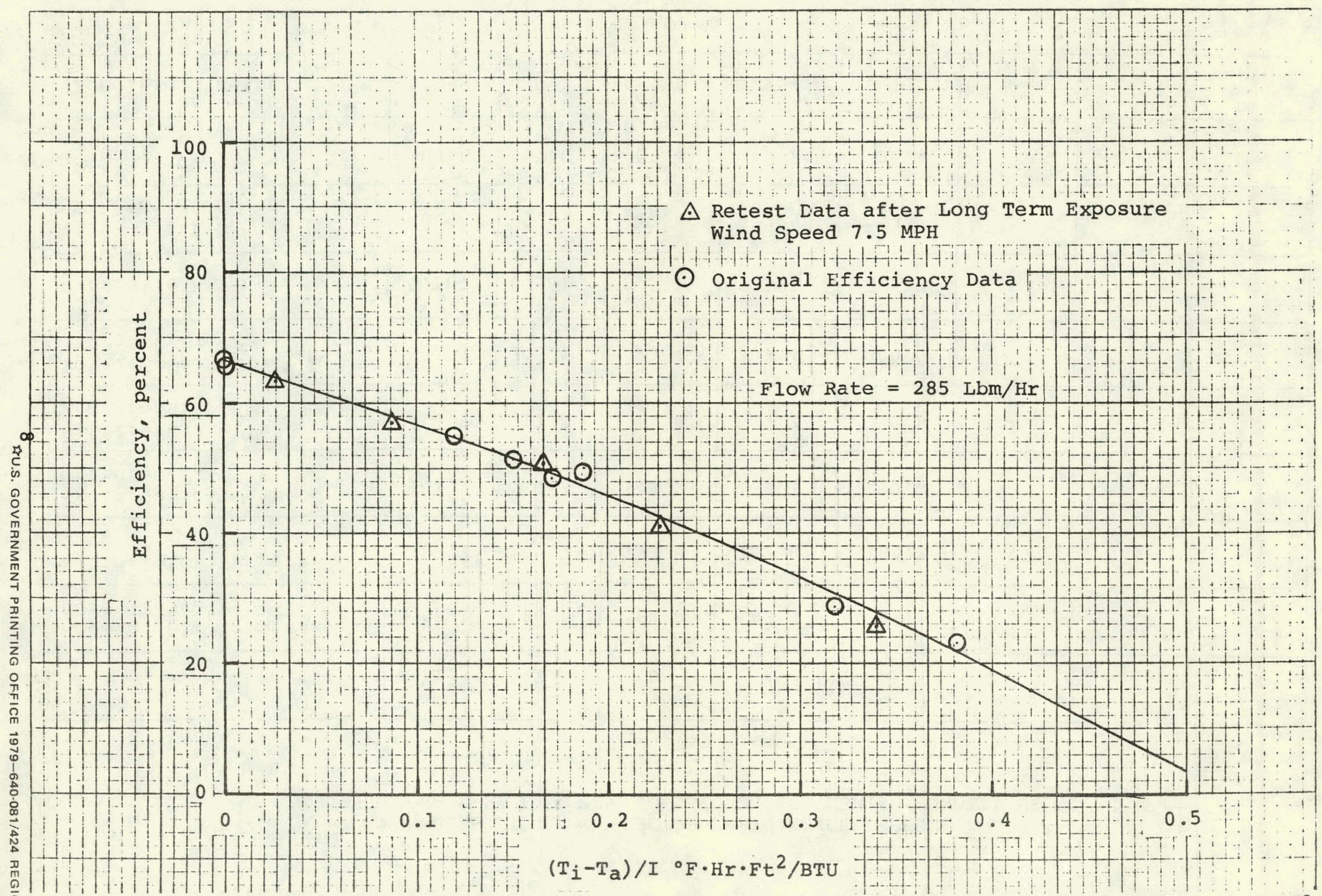

Figure 1. Comparison of Themal Performance of Sunworks Iiquid Collector Before NASA-MSF and After Long Term Exposure to Natural Weathering Conditions 